\title{
Teaching with Difference: A Response to Angela Calabrese Barton: Teaching Science with Homeless Children: Pedagogy, Representation, and Identity
}

\author{
Deborah Loewenberg Ball, ${ }^{1}$ Margery D. Osborne ${ }^{2}$ \\ ${ }^{1}$ School of Education, University of Michigan, 610 East University Avenue, \\ Ann Arbor, Michigan 48109-1259 \\ ${ }^{2}$ Department of Curriculum and Instruction, College of Education, 311 Education Building, \\ University of Illinois at Champaign-Urbana, 1310 South Sixth Street,
} Champaign, Illinois 61820-6990

This article poses a vital question: Of whom are we thinking when we dream of an education for "all?" What does education for "all" really entail? Would an education for "all" look fundamentally different from the education we are now trying to enact? Many schemes for educating "all" are little more than translations of the current curriculum and modal pedagogy. "All" children are somehow benignly the same. "All" is not a word that carries heterogeneity: It suggests instead likeness and similarity. It implies children who are "different" slowly becoming more like all of us (whoever we are). Barton's article (Barton, 1998) about her work with homeless children suggests that educating all students entails going beyond seeking ways to enable marginalized students to engage in present educational forms. Rather, an education for homeless and minority children involves rethinking foundational assumptions about the nature of the disciplines, the purposes of education, and our roles as teachers. It does not mean remaking those children into our own images. For Barton, it meant remaking science in the children's image.

Other writers have suggested such rethinking about education in general and in fields other than science (for example, Delpit, 1988; 1992; Gates, 1992; hooks, 1994; McIntosh, 1983; West, 1993; Weller, 1988). Barton, though, provides a vivid image of what it might mean to do this remaking in science. Science can be shaped and responsive to our experiences of the phenomena of our surrounding world-whether in puzzling about pollution and its effects on our surroundings or in inventive cooking. Barton and the girls with whom she is exploring this creative remaking of science are not coincidentally exploring the territory of habitat and food, essentials in the reality of homeless children. Their investigations are neither sentimental nor trivial. Situated in the surrounding realities of their lives, the inquiries are authentically interdisciplinary: The exploration of how pollution affects the lived experience of the neighborhood is an inquiry permeated with sociology and psychology; the experimentation with food, a play of chemistry threaded with the aesthetics of taste and appearance. These are real projects. They

Correspondence to: M.D. Osborne 
use science and they connect with the real lives and concerns of these children. They also make and remake science. Such science is fundamentally true to the vision of the disciplines and teaching described by John Dewey (1902/56) as well as Paulo Freire (1970), for it connects to children's experiences in the most authentic way imaginable. Because Barton makes these connections primary as she constructs her pedagogy, this vision is also a creative revisioning of what science can be for these children.

In our society, the question of what to do with difference in our classrooms has been a perennial one. As teachers, we know that every child is different behaviorally and in background, in interests and ability. Sometimes we celebrate that difference, but other times that difference is a barrier-it gets in the way of our teaching (Ball, 1993; Lensmire, 1993; Osborne, in press). How to take account of and respond to differences among our students is a central question in teaching, extending from our worries about how to figure out what students are learning to pondering ways to engage all our students in what we are teaching-from physics to writing, art to mathematics.

Barton reminds us of fundamental questions about teaching with difference. For example: How is difference constructed? and Why does difference matter? When she asks those questions, she would like us to examine a more foundational one: From where do mainstream norms and expectations come? When we ask that question, we are looking at both our expectations about "normal" behavior and also our beliefs about what is mainstream knowledge in a particular discipline. Why should we take it for granted that a child should act in a certain way in school or that he or she should even want to? We need to ask those questions if we want to make claims about constructing "a science for all."

What Barton has done pedagogically-in the construction of science curriculum and in her relationships with children-helps us to recognize the links between content and students and how these links must be altered for the marginalized to engage in science. Underlying her discussion of approaches to dealing with diversity is a questioning of what those courses of action imply about attitudes toward difference. Do they imply that difference is something to be "fixed" or changed, or that difference should be worked within and maybe finally respected? Underneath all of this is, of course, the driving question for teachers: How does one teach all children?

Finally, Barton's stories cause us to think about what educational responses to diversity entail. Respecting diversity in the way we educate children does not mean seeking to homogenize. Respecting diversity does imply changes in societal norms. It implies that our ideas about subject matter, our assumptions about good behavior, home life, interests, and goals will evolve and enlarge. As Barton's work with homeless children reveals, such transformations in how we understand society and its relationship to schooling are at the heart of creating new educational responses to diversity.

\section{References}

Ball, D.L. (1993). Halves pieces and twoths: Constructing representational contexts in teaching fractions. In T.P. Carpenter (Ed.), Rational numbers (pp. 157-195). New York: Erlbaum.

Barton, A.C. (1998). Teaching science with homeless children: Pedagogy, representation, and identity. Journal of Research in Science Teaching, 35, 379-394.

Delpit, L.D. (1988). The silenced dialogue: Power and pedagogy in educating other people's children. Harvard Educational Review, 58, 280-298.

Delpit, L.D. (1992). Acquisition of literate discourse: Bowing before the master? Theory into Practice, 31, 296-302. 
Dewey, J. (1902/1956). The child and the curriculum. Chicago: University of Chicago Press.

Freire, P. (1970). Pedagogy of the oppressed. New York: Continuum.

Gates, H.L. (1992). Trading on the margin: Notes on the culture of criticism. In H.L. Gates (Ed.), Loose canons. New York: Oxford University Press.

hooks, b. (1994). Teaching to transgress: Education as the practice of freedom. New York: Routledge.

Lensmire, T.J. (1993). Following the child, socioanalysis, and threats to community: Teacher response to children's texts. Curriculum Inquiry, 23, 265-299.

MacIntosh, P. (1983). Interactive phases of curricular re-vision: A feminist perspective. Working Paper 124. Wellesley, MA: Center for Research on Women.

Osborne, M.D. (In press). Responsive science pedagogy in a democracy: Dangerous teaching. Theory into Practice.

Weiler, K. (1988). Women teaching for change: Gender, class and power. South Hadley, MA: Bergen and Garvey.

West, C. (1993). Black critics and the pitfalls of canon formation. In West, C. (Ed.), Keeping the faith: Philosophy and race in America (pp. 33-43). New York: Routledge. 